\title{
Research on the Construction of Double-certificated Teachers in Professional and Applied Universities \\ YONG Chunguang
}

\author{
Baicheng Normal University, Baicheng, 137000, China \\ email: xiaoyong0619@163.com
}

Keywords: Double-certificated, Construction, Tactics

\begin{abstract}
To build a "double- certificated" teaching team, which can be adapted to the employment-oriented and emphasize the demands of skill and practical teaching, is the core of cultivating professional applied talents. At the same time, it is also the main development direction of the construction of applied and efficient teachers in our country at present and even in the future. With the rapid development of higher vocational education in our country at present, the enrollment scale is expanding year by year. While developing higher vocational education vigorously, higher standards and requirements have been put forward for the construction of teachers, especially when the teachers of vocational education with weak practical ability and lack of rich practical experience are carrying out the construction of "double- certificated" teaching staff. This paper briefly introduces the connotation of double- certificated teachers, and then through the analysis of the problems existing in the construction of double- certificated teachers, puts forward some improvement strategies..
\end{abstract}

\section{Introduction}

In the long-term development of vocational education in our country, how to train teachers with both theoretical and practical abilities has always been a key issue. In order to carry out the spirit of the outline of the education plan and strengthen the construction of the "double- certificated" teachers in vocational education, during the 12th Five-Year Plan period, The Ministry of Education and the Ministry of Finance jointly issued the "Opinions on the plan for improving the quality of teachers in vocational colleges", which set up a training project for backbone teachers, and a project on the practice of secondary vocational teachers in enterprises. Part-time teachers' appointment and promotion projects, as well as the construction of the teacher training system, four projects, Therefore, it is of great practical significance to carry out relevant research work on the construction of professional applied type "double- certificated" teachers in vocational colleges and universities.

\section{The Connotation of "Double- certificated" Teachers}

"Double- certificated" teacher does not refer to a "double certificate" teacher who has a teacher's qualification certificate and relevant professional and technical qualification certificate or professional title. In particular, it refers to a teacher who is qualified for vocational education at the same time, They also have the ability and quality of relevant engineering and technical personnel, and to be able to integrate this theory and practice, ability and attitude into the daily education and teaching work, only can meet this standard requirements. In order to be called "double- certificated" teachers, the interpretation of "double- certificated" teachers emphasizes the ability of integrating theory and practice, that is, the ability of teachers and engineers. It is true that teachers can internalize their qualities and professional skills in the course of their daily teaching by internalizing their qualities and professional skills. At the same time, it is combined with its teaching ability and quality to form a new kind of ability and quality. This new type of ability and quality will urge "double- certificated" teachers not only to teach students with high quality of specialized knowledge content, To strengthen students' learning efficiency, at the same time, it can exert a subtle influence on students in the course of daily teaching, promote students to form good professional ethics, and urge students not only to grasp the relevant theoretical knowledge points deeply. At the same time, 
it can also skillfully apply the professional skills, improve professional quality, and lay a solid foundation for students to work[1].

\section{Problems in the Construction of "Double- certificated" Teachers}

The source of professional applied university teachers is relatively single, which also determines the scarcity of "double- certificated" teachers. There is still not a small gap between the requirements of building a "double- certificated" teaching team. Besides the shortage of "double- certificated" teachers, the educational structure is on the low side and the age structure is unreasonable. The single structure of academic edge is also an important reason to affect the construction of professional applied-oriented "double- certificated" teachers[2].

The Number of "Double- Certificated" Teachers Is Insufficient. Although more and more colleges and universities have begun to realize the importance of building a "double- certificated" teaching staff, they have also started to work on the construction of "double- certificated" teachers step by step, aiming at full-time teachers to have a certain practical ability. At the same time, some measures have been taken. However, the proportion of double- certificated teachers in the teaching staff of colleges and universities has not been effectively promoted in view of the actual situation at present[3]. According to a report on nearly 120 higher vocational colleges and universities throughout the country, the proportion of double- certificated teachers in colleges and universities has not been effectively increased. The findings of the. The percentage of double- certificated teachers in higher vocational, technical and technical colleges is $47.5 \%$ and 19.80 .The proportion of double- certificated teachers falls far short of the requirements of "opinions on teacher quality improvement Plan" put forward by the Ministry of Education.

"Double- Certificated" Teachers' Academic Structure Is on the Low Side. At present, among the teachers of higher vocational colleges in China, most of them are based on the level of undergraduate education, and the teachers with master's degree or above are relatively few. This is also a major problem that higher vocational colleges are facing. As an auxiliary part of higher education, there is a certain gap between higher vocational education and the requirements of teachers' academic qualifications in general colleges and universities. This is determined by the reality. At present, most higher vocational colleges are developed from the original adult education, technical secondary school, high school or private college. Most of the teachers in this part of the university are at the teaching level of the technical secondary school level, and their academic qualifications have yet to be improved, and even some teachers have only a specialized degree. This also makes the overall level of higher vocational education and the requirements of the country there is not a small gap, and about the "double- certificated" team of teachers is even more difficult to talk about[4].

The Age Structure of "Double- Certificated" Teachers Is Unreasonable. At present, the age structure of the "double- certificated" teachers in higher vocational colleges in China shows that more than $86 \%$ of the "double- certificated" full-time teachers are under 40 years old. A large number of middle-aged and young teachers have greatly changed the age structure of the teaching staff. It has laid a solid foundation for the development of higher vocational colleges and universities. But at the same time, it should be noted that although young teachers can inject fresh blood into the "double- certificated" faculty building, But teachers in this age group are also at a critical turning point in their personal lives, with limited energy to devote themselves to work and younger teachers compared to older teachers. There is still a lot of room for improvement in the sense of responsibility and dedication to education, which is not enough for students to inculcate. Young teachers need long-term accumulation of daily teaching and professional skills, so it is necessary to strengthen the systematic training of this part of teachers. Considering the practical characteristics of higher vocational education, we can expand the proportion of middle-aged teachers[5].

The Structure of "Double- Certificated" Teacher's Learning Margin Is Single. At present, the full-time teachers of higher vocational colleges in our country mainly include the direct teaching after graduation, the transfer of other colleges and universities, the transfer of scientific research 
institutions and the transfer of enterprises into these four ways. For the "double- certificated" teachers, it is basically the same[6]. Among them, the proportion of teachers who teach directly from higher education institutions is the largest, followed by those transferred from other universities, while the proportion transferred from scientific research institutions to enterprises is relatively low. This also leads to a single source approach for "double- certificated" teachers. It is common for teachers to emphasize theory rather than practice. Too much attention is paid to the teaching of theory, but there are few teachers who have the ability of hands-on practice. Most teachers in higher vocational colleges walk directly from the classroom to the podium after graduation, lacking practical work experience and operational ability. In particular, few young teachers have the ability to practice. Moreover, in terms of the current teaching conditions in higher vocational colleges, the opportunities and places for teachers to operate in practice are also very inadequate. Most higher vocational colleges have not established the educational model of integration of production and teaching, and the enterprises lack positive motivation for teachers to participate in the job production, and most of the joint talents training models signed with the schools are aimed at the employment of students. And "double- certificated" teacher training failed to establish an effective link.

\section{Construction Strategy of "Double- certificated" Teachers in Professional and Applied Universities}

We will Increase Social Support and Provide Policy Support. In order to further promote the construction of double- certificated teachers in higher vocational colleges, the relevant government departments must continuously strengthen the investment of funds and policies in vocational education in order to promote the training of skilled personnel in multi-level and multi-professional fields. To be able to raise the role of "double- certificated" teachers to the height of a highly skilled and powerful country, to form a broad recognition of "double- certificated" teachers in the whole society, and to make this part of the teachers be respected and valued by the whole society. In order to create a good job for "double- certificated" teachers, it is necessary to create a culture of striving to become "double- certificated" teachers in the professional teacher collectively. In addition, the state should also set up a steering committee on "double- certificated" teacher review as soon as possible. To formulate specific measures and methods for evaluating "double- certificated" teachers. After carrying out part of the pilot activities, gradually expand the promotion. At the same time, take into account the actual situation in each specific industry, "doubledoub-\#en1\#" teachers will be divided into primary and middle level. In order to promote the rapid development of "doublecertificated" teachers in higher vocational colleges, it is possible for them to be close to the relevant professional titles of teachers in ordinary colleges and universities, and to promote the rapid development of "double- certificated" teachers in higher vocational colleges[7].

We will Perfect the Training Mechanism of "Double- Certificated" Teachers in Higher Vocational Colleges. In the construction of double- certificated teachers, schools always play an important leading role. Subject to the policy and system and other conditions, the introduction of "double- certificated" teachers can not become the absolute main body of teachers. Therefore, it is necessary for the relevant higher vocational colleges to combine their own actual conditions, to create favorable conditions, to strengthen the training of existing teachers in the school, and to provide certain incentive policies in the aspects of salary treatment, working conditions and job title selection, etc. Accelerate the construction of "double- certificated" teachers. The key to the training of vocational education teachers is to be able to train teachers who are fully qualified for vocational education. That is, "double- certificated" teachers. At present, the mode of training the qualifications of teachers in vocational education in our country is still the mode of training the qualifications of ordinary teachers, that is, the school-based training mechanism. Conventional classroom theoretical learning accounts for the majority of the proportion. However, entering enterprises or schools for internships often lasts only about a month, while graduates transferred from ordinary colleges and universities do not even have any internship experience at all. Many new teachers have no knowledge of the working environment and nature of their future jobs and 
lack training conditions. This will not only lead teachers to experience a long period of adaptation, but also affect the effectiveness of teaching. In this case, we can build a "double- certificated" teacher training base and start a "double- certificated" teacher education network university. The implementation of the previous measure, Leading by relevant government departments, we can set up a high level vocational education training base which can meet the needs of cultivating skilled talents on a certain scale. The construction of this kind of training base is different from normal university education. It is a kind of school specially set up to deal with the shortage of "doublecertificated" teachers in colleges and universities. The implementation of the latter measure is a strategic measure adopted by modern vocational education in response to the challenge of information society. In carrying out the course teaching of online education university, we should draw up a precise plan, and divide it into several stages to gradually implement it. The establishment is led by the government department, including the formulation of educational policy, content and qualification standard. In order to provide some basic conditions for teachers' learning practicability, skill and science, open educational institutions with characteristics are incorporated in the actual teaching process[8].

We will Rely on Teachers to Promote the "Double- Certificated" Teacher Professional Development. Some studies have pointed out that teachers in the first few years of teaching work, along with the continuous accumulation of their work experience, teaching results will continue to improve, but after the fifth year of teaching work, The teaching methods and knowledge have been basically stable, and the teaching level of teachers will also meet the bottleneck period. Therefore, it is necessary to absorb new knowledge actively, that is, to form the idea of lifelong learning while carrying out teaching work. By investing in learning new knowledge, education can be organically integrated with daily work. With the rapid development of various kinds of new information technology, it has a more and more profound influence on the educational work, and in the educational thought and content, Methods and other aspects have brought great changes. If teachers can not update their own professional knowledge in time, they will be eliminated by the times. Therefore, we should strengthen the full application of all kinds of new teaching methods and improve the classroom teaching effect. When training teachers' practical ability, they can be implemented in the following three aspects: first, the school should arrange teachers to participate in the production work in line with the enterprises they teach; second, set up an internship base in the school to put into production activities and carry out teaching instruction; third, work together with enterprises to develop infrastructure and invest in the design activities of various production processes. Teachers should be able to clearly define the practical teaching system, Based on this, we should fully understand the production and operation process of the enterprise, grasp the dynamic changes of the development of the industry, be able to flexibly apply teaching cases in the daily teaching process, explore, summarize and introduce various professional education and teaching models. Changing the traditional way of teaching knowledge and knowledge can make the daily classroom teaching be closely related to the practice of production, enrich the form of classroom teaching and improve the teaching effect.

\section{Conclusion}

In a word, from the point of view of the development needs of professional applied colleges and universities, it is urgent to strengthen the construction of the teaching staff. And "doublecertificated" teaching team construction is also the key and foundation to ensure that professional applied colleges and universities can better carry out the daily classroom teaching work. The construction of "double- certificated" teaching team in professional applied universities is the most critical one. The goal of the work is to improve the quality of teaching, In view of this, this paper puts forward some strategies such as increasing social support, providing policy guarantee, perfecting "double- certificated" teacher training mechanism in higher vocational education, relying on teachers' main body to promote "double- certificated" teachers' professional development and so on, in order to promote the long-term development of professional applied colleges and universities. Sustainable development provides some references. 


\section{References}

[1]PANG Hefeng, BO Yuming, KONG Jie. The Present Situation and Strategy of Training "Double- certificated" Teachers in Colleges and Universities[J]. Education and Vocation, 2015, (34):57-59.

[2]HU Jianhua. Study on the "Double- certificated" Development of Applied Technology Teachers in Colleges and Universities[J].Continue Education Research,2016,(9):88-90.

[3]SUN Hongbo, CAI Chujun. A Study on the Path of University Transformation and the Construction of "double- certificated" Teachers-Taking the Specialty of Product Design in Application-oriented Colleges and Universities as an Example[J].Art Education Research, 2017, (14): 80-81,83.

[4]YU Fang. A Probe into the Path of "Double- certificated" Teachers Construction in Applied undergraduate Colleges and Universities[J].Teachers,2017,(5):125-126.

[5]WANG Zhonghua. The Dilemma and Way out of the Construction of Double- certificated Teachers in the Transformation of Local Colleges and Universities[J].Journal of Nanchang Normal University,2016,37(2):41-45.

[6]YU Yuelan. A Comparative Study on the Training Mode of "Double- certificated" Teachers in Chinese and Foreign Universities[J].Economic \& Trade,2017,(19):325.

[7]QIAN Shuxia, YU Yanhua, WU Chunyan. Study on the Present Situation, Problems and Effective Ways of the Construction of "Double- certificated" Teachers in Local Universities[J]. Education Teaching Forum,2017,(5):19-20.

[8]YANG Shouliang, YANG Baoliang, ZENG Linggang. Study on the Ways to Improve the Teaching Ability of "Double- certificated" Teachers in Applied undergraduate Colleges and Universities[J].Education Teaching Forum,2014,(28):279-280,281. 